KAMIL BARC

287023@stud.umk.pl

ORCID: 0000-0003-1896-0336

KATARZYNA ŁAWROWSKA

287291@stud.umk.pl

ORCID: 0000-0003-2220-6635

\title{
Przymusowy urlop wypoczynkowy jako subsydiarny mechanizm organizacji i porządku pracy w dobie pandemii
}

\author{
Forced annual leave as a subsidiary mechanism of organization and order of work in a time of \\ pandemics
}

Streszczenie. Niniejszy artykuł podejmuje tematykę udzielenia zaległego urlopu oraz modyfikacji, które zostały wprowadzone w tym zakresie w ramach ustaw mających zapobiegać negatywnym skutkom pandemii COVID-19. Autorzy zestawiają dotychczas funkcjonujący model udzielenia zaległego urlopu z modyfikacją, która pozwala pracodawcy na arbitralne skierowanie pracownika na zaległy urlop. Piszący kreują tezę, wedle której norma wprowadzona na podstawie ustawy specjalnej posiada przymiot subsydiarności w stosunku do ogólnej normy zawartej w Kodeksie pracy. Nadto autorzy prognozują formę i strukturę instytucji urlopu wypoczynkowego po okresie pandemii.

\begin{abstract}
This article is about the subject matter of the granting of outstanding leave and the modifications which have been introduced of the laws intended to prevent the negative effects of the COVID-19 pandemic. The authors have compared a functioning model for the granting of outstanding leave with a modification that allows the employer to arbitrarily grant the worker on the overdue leave. The authors create the argument that the standard introduced by the special law is subject to a quality of subsidiarity in relation to the general rule contained in the Labour Code. In addition, the authors predict the form and structure of the annual leave institution after a pandemic period.
\end{abstract}

Słowa kluczowe: urlop zaległy; covid-19; gwarancje systemu prawa pracy; udzielanie urlopu.

Key words: overdue leave; covid-19; guarantees of the labour law system; grant of leave. 


\section{Wstęp}

Tematyka statusu pracownika jest zagadnieniem wielopłaszczyznowym i skomplikowanym w swojej strukturze. Dokonanie właściwej analizy oraz oceny zjawiska, będącego ściśle powiązanym z szeroko rozumianymi prawami i obowiązkami pracownika, musi opierać się na właściwym odtworzeniu omawianych norm, zestawienia tychże norm z podstawowymi zasadami prawa pracy oraz prognozy dotyczącej efektywności kreowanego prawa. Dzisiejsze prawodawstwo w znacznym stopniu zostało zdeterminowane przez skutki pandemii wirusa COVID-19. Oddziaływanie owych skutków zostało zaznaczone w wielu aspektach życia, takich jak: sfera gospodarcza, ekonomiczna, społeczna. W kontekście powyższego prawodawca zobligowany został do kreacji takich norm, które to w jak największym stopniu będą hamować negatywne konsekwencje obecności wirusa COVID-19. W zakresie norm dziedziny prawa pracy ustawodawca stanął przed dylematem, który w rzeczywistości jest immanentnym czynnikiem tworzenia norm tej gałęzi prawa. Wprowadzając normy aktualne na czas stanu epidemii oraz stanu zagrożenia epidemiologicznego, musiał albo zwiększać aspekty gwarancyjne w kontekście pracownika, albo też nadać konkretne „przywileje” pracodawcy. Te przywileje nie zamykają się jedynie $\mathrm{w}$ relacji pracodawca-pracownik, ale w założeniu swoje oddziaływanie mają na cały obrót gospodarczy. Niniejsza praca podejmuje tematykę urlopu wypoczynkowego oraz zmian, które w tym zakresie zostały zawarte w ustawie z dnia 2 marca $2020 \mathrm{r}$. o szczególnych rozwiązaniach związanych z zapobieganiem, przeciwdziałaniem i zwalczaniem COVID-19, innych chorób zakaźnych oraz wywołanych nimi sytuacji kryzysowych ${ }^{1}$. Autorzy poprzez dokładną analizę założeń prawodawcy, konstrukcję legislacyjną, a także systemowe umiejscowienie normy pragną dokonać oceny zasadności takiej regulacji, jej zgodności z całym systemem dziedziny prawa pracy, a także dokonać odpowiedniej prognozy odnoszącej się do zmiany w pozaprawnych relacjach pracownika i pracodawcy.

\section{Założenia badawcze}

Celem wizualizacji oraz zwiększenia przejrzystości proponowanej analizy zasadnym wydaje się wskazanie założeń, na podstawie których sformułowane zostały modele interpretacyjne oraz wnioski i ocena regulacji. Punktem wyjścia do rozważań jest zestawienie dwóch norm prawnych regulujących tematykę wykorzystania zaległego urlopu. Dla wykazania różnic między wskazanymi normami autorzy wprowadzają termin „reżimów prawnych”, tj. reżimu kodeksu pracy oraz reżimu ustawy z dnia 2 marca 2020 r. o szczególnych rozwiązaniach związanych z zapobieganiem, przeciwdziałaniem i zwalczaniem COVID-19.

\footnotetext{
${ }^{1}$ Ustawa z dnia 2 marca 2020 r. o szczególnych rozwiązaniach związanych z zapobieganiem, przeciwdziałaniem i zwalczaniem COVID-19, innych chorób zakaźnych oraz wywołanych nimi sytuacji kryzysowych (tekst jedn.: Dz.U. z 2020 r. poz. 374).
} 
Zestawienie to odbywa się na kilku płaszczyznach. Pierwszą z nich jest płaszczyzna walidacyjna. W kontekście proponowanych modelów interpretacyjnych płaszczyzna ta wydaje się być kluczowa. Właściwe rozstrzygnięcie tej kwestii pozwoli na rozstrzygnięcie obowiązywania obu reżimów albo czasowe wyłączenie z obrotu prawnego reżimu kodeksowego.

Kolejną sferą rozważań staje się zagadnienie temporalne. Składowymi tej sfery są dwa elementy: ograniczenie czasowe zastosowania reżimu kodeksowego oraz ograniczenie ilościowe reżimu ustawy specjalnej.

\section{Podstawowy model urlopu wypoczynkowego}

Podejmując refleksję nad szczególnym uregulowaniem kwestii urlopów wypoczynkowych w związku ze stanem epidemii, należy rozpocząć od budowy ogólnego modelu, który to w związku z aktualizacją normy specjalnej ulega odpowiednim modyfikacjom. Definiując figurę prawną urlopu, posłużyć należy się definicją, zgodnie z którą jest to przerwa w wykonywaniu pracy ${ }^{2}$. Jest ona zagwarantowana przepisami prawa i przysługuje w okresach konkretnie określonych ${ }^{3}$. Wskazując cechy takiej przerwy, należy uwypuklić, iż jest ona: coroczna, nieprzerwana, płatna ${ }^{4}$. Głównym przeznaczeniem urlopu wypoczynkowego jest regeneracja sił pracownika po dłuższym okresie pracy ${ }^{5}$. Zgodnie z normą wynikającą z art. $152 \S 2$ k.p. pracownik nie może zrzec się prawa do urlopu ${ }^{6}$. Powyższa regulacja znajduje swoje uzasadnienie w celu urlopu wypoczynkowego, który to cel implikuje charakter prawa do urlopu jako prawa podmiotowego oraz osobistego, którego nie można przenieść na inną osobę 7 . Zasada ta została potwierdzona przez orzeczenie Sądu Najwyższego z dnia 7 lutego 1967 r.,w którym to stwierdzono, iż „Pracownik nie tylko w umowie o pracę, lecz także w czasie jej trwania nie może skutecznie zrzec się prawa do urlopu wypoczynkowego i to zarówno bieżącego, jak i zaległego, jeśli urlop może jeszcze wykorzystać"». W ujęciu praktycznym będzie to oznaczać, iż zrzeczenie się urlopu przez pracownika jest nieważne. Po dokonaniu takiego zrzeczenia pracownik nadal może ubiegać się o

\footnotetext{
${ }^{2}$ M. Jaroszewska, Ogólna charakterystyka czasu wolnego i prawa do urlopu wypoczynkowego w: Urlopy wypoczynkowe, Warszawa 2014, LEGALIS nb 2.

${ }^{3}$ Tamże, nb 2.

${ }^{4}$ L. Florek, Prawo pracy, Warszawa 2019, s. 181.

5 M. Zieleniecki, Urlopy pracownicze w: Kodeks pracy. Komentarz. red. A. Sobczyk, Warszawa 2020, LEGALIS nb 2.

${ }^{6}$ Ustawa z dnia 26 czerwca 1974 r. Kodeks pracy (tekst jedn.: Dz.U.1974 r. Nr 24 poz. 141).

${ }^{7}$ M. Nałęcz,Urlopy pracownicze w: Kodeks pracy. Komentarz. red. W. Muszalski, Warszawa 2019, nb 11.

${ }^{8}$ Wyrok SN z dnia 7 lutego 1967 r., I PR 53/67, OSPiKA 1967 r., z. 12, poz. 287.
} 
skorzystanie z przysługującego mu urlopu'. Wymiar nabytego urlopu określany jest na podstawie art. 154 k.p., zgodnie z którym wysokość udzielonego urlopu uzależniona jest od okresu zatrudnienia ${ }^{10}$. W kontekście omawianego tematu kluczowe znaczenie posiadają normy regulujące kwestię organizacji przyznawania urlopu wypoczynkowego oraz najpóźniejszego wykorzystania przysługującego urlopu. $\mathrm{Z}$ treści art. 161 k.p. wynika obowiązek pracodawcy do przyznania urlopu pracownikowi w roku, $\mathrm{w}$ którym to pracownik nabył do niego prawo. Wyrażona norma pozostaje w ścisłym związku z cechą urlopu, jaką jest jego coroczność ${ }^{11}$. W doktrynie wskazuje się na fakt, iż brak przyznania pracownikowi urlopu w roku, w którym to nastąpiło jego nabycie, stanowi przesłankę popełnienia wykroczenia przeciwko prawom pracownika. Fakt niechęci realizacji prawa do urlopu przez pracownika nie zwalnia z odpowiedzialności tytułem nieudzielenia takiego urlopu ${ }^{12}$. Chęć kumulacji czasu urlopu wypoczynkowego może prowadzić do reakcji ze strony pracodawcy, po którego stronie aktualizuje się możliwość zastosowania kary porządkowej ${ }^{13}$. Powyższe stanowisko wydaje się mieć uzasadnienie w świetle obowiązującego art. 108 k.p. Wydaje się, iż umyślne utrudnianie realizacji obowiązku pracodawcy może być uważane za zachowanie nieprzestrzegania przez pracownika ustalonej organizacji i porządku w procesie pracy. Zaległości urlopowe powstałe z przyczyn leżących po stronie pracownika nie będą uprawniać pracodawcy do zastosowania kary porządkowej jedynie w sytuacji, kiedy to brak wykorzystania urlopu spowodowany został przez zdarzenie uniemożliwiające wykorzystanie urlopu wypoczynkowego. Takie zdarzenia będą stanowić przesłankę zwalniającą z odpowiedzialności za wykroczenie przeciw prawom pracownika również pracodawcę ${ }^{14}$.

Kumulacja urlopu po stronie pracownika nastąpić może w związku z wykorzystaniem uprawnień, które swoje źródło mają w normach art. 164 i 165 k.p. Odtwarzając znaczenie tychże

\footnotetext{
${ }^{9}$ J. Wratny, Kodeks pracy. Komentarz., Warszawa 2016, LEGALIS nb 6.

${ }^{10}$ Art. 154. § 1 k.p.: Wymiar urlopu wynosi:

1) 20 dni - jeżeli pracownik jest zatrudniony krócej niż 10 lat,

2) 26 dni - jeżeli pracownik jest zatrudniony co najmniej 10 lat.
}

$\S 2$. Wymiar urlopu dla pracownika zatrudnionego w niepełnym wymiarze czasu pracy ustala się proporcjonalnie do wymiaru czasu pracy tego pracownika, biorąc za podstawę wymiar urlopu określony w $\S 1$; niepełny dzień urlopu zaokrągla się w górę do pełnego dnia.

$\S 3$. Wymiar urlopu w danym roku kalendarzowym, ustalony na podstawie $\S 1$ i 2 , nie może przekroczyć wymiaru określonego $\mathrm{w} \S 1$.

${ }^{11}$ M. Zieleniecki, Urlopy... red. A Sobczyk, Warszawa 2020, LEGALIS Art. 161 k.p. nb 1.

${ }^{12}$ M. Nałęcz, Urlopy... red. W. Muszalski, Warszawa 2019, LEGALIS nb 1.

${ }^{13}$ K. Walczak, Kilka uwag na temat zatrudnienia $w$ dobie pandemii i po jej zakończeniu, Monitor Prawa Pracy 2020, Nr 6, s. 10.

${ }^{14}$ M. Nałęcz, Urlopy... red. W. Muszalski, Warszawa 2019, LEGALIS art.161, nb 2. 
norm, należy wskazać, iż występuje tutaj swoista gradacja. Zasięg dyskrecjonalnej władzy pracodawcy w zakresie przesunięcia urlopu na wniosek pracownika limitowany jest przesłanką, która uprawnia pracownika do złożenia takiego wniosku. W sytuacji bowiem, gdy inicjatywa pracownika za swoją podstawę przyjmuje ,umotywowane przyczyny”, wówczas w gestii pracodawcy pozostaje wyrażenie zgody na takie przesunięcie. W literaturze przedmiotu wskazuje się, iż znaczenie terminu „umotywowane przyczyny” rozciąga się na zdarzenia natury osobistej lub rodzinnej ${ }^{15}$. Natomiast znaczne ograniczenie luzu decyzyjnego pracodawcy w zakresie podjęcia decyzji o przesunięciu urlopu następuje w sytuacji, kiedy to przyczyną przesunięcia urlopu są przyczyny usprawiedliwiające nieobecność w pracy. Wskazany w niniejszym artykule katalog przyczyn ma charakter otwarty i może być uzupełniany o inne zdarzenia ${ }^{16}$. Zgodnie bowiem z $§ 1$ Rozporządzenia Ministra Pracy i Polityki Socjalnej w sprawie sposobu usprawiedliwiania nieobecności w pracy oraz udzielania pracownikom zwolnień od pracy za usprawiedliwione przyczyny nieobecności w pracy uznaje się takie zdarzenia, które określone są przepisami prawa pracy, a także takie, które zostały wskazane przez pracownika i uznane przez pracodawcę. Wydaje się, iż kumulacja dni urlopowych może nastąpić również poprzez umiejętne wykorzystanie normy wynikającej z art. 162 k.p. poprzez pozostawienie rezerwy w postaci niezaplanowanych dni urlopowych ${ }^{17}$. Jest to jednak swoiste nadużycie norm prawa pracy i jako takie nie zasługuje na aprobatę.

\section{Modelowe wykorzystanie zaległego urlopu}

Powyższe rozważania prowadzą do głównego zagadnienia niniejszej analizy, tj. do normy stanowiącej o najpóźniejszym wykorzystaniu urlopu. Właściwe rozumienie normy wynikającej z art. 168 k.p. implikować będzie ocenę zasadności zmian wprowadzonych na czas trwania epidemii lub zagrożenia epidemiologicznego. Omawiana norma nakłada termin wykorzystania urlopu zaległego. Kluczowym w tym elemencie wydaje się odpowiednie rozumienie dyskrecjonalnej władzy pracodawcy. Należy więc udzielić odpowiedzi na pytanie, czy pracodawca, realizując obowiązek narzucony przez normę art. 168 k.p., jest władny do kierowania pracownika na zaległy urlop niezależnie od jego potrzeb oraz zgody. Kwestia zgody pracownika na skierowanie go na urlop zaległy jest przedmiotem sporu uwidocznionego w sferze orzeczniczej. W wyroku Sądu Najwyższego z dnia 2 września 2003 roku znajdujemy tezę, zgodniez którą pracodawca nie jest obowiązany do uzyskania zgody pracownika na

\footnotetext{
${ }^{15}$ J. Wratny, Kodeks... 2016, LEGALIS, art. 164, nb 1.

${ }^{16}$ M. Zieleniecki, Urlopy... red. A Sobczyk, Warszawa 2020, LEGALIS Art. 161 k.p. nb 1.

17 Art. 162 k.p.: Na wniosek pracownika urlop może być podzielony na części. W takim jednak przypadku co najmniej jedna część wypoczynku powinna trwać nie mniej niż 14 kolejnych dni kalendarzowych.
} 
skierowanie pracownika na zaległy urlop ${ }^{18}$. Nadto Sąd wskazywał, iż pracodawca zobligowany jest do udzielenia urlopu pracownikowi w terminie narzuconym przez ustawę ${ }^{19}$. Podobne stanowisko zajął Sąd Najwyższy w wyroku z dnia 7 maja 2008 roku w sprawie o sygn. akt II PK 313/07, w którym stwierdza, iż z art. 168 k.p. wynika obowiązek pracodawcy do udzielenia pracownikowi zaległego urlopu i w tym zakresie nie jest wymagana zgoda pracownika ${ }^{20}$. Jednakże w wyroku z dnia 25 sierpnia 2004 roku Sąd Najwyższy stwierdził, iż nie można jednoznacznie określić, czy pracodawca jest władny jednostronnie skierować pracownika na zaległy urlop. Zdaniem Sądu Najwyższego właściwa odpowiedź na to pytanie uzależniona jest od konkretnego stanu faktycznego i jego okoliczności ${ }^{21}$. Uwzględniając interesy obu stron, należy opowiedzieć się za stanowiskiem w uprzywilejowanej roli stawiającym pracodawcę. Zdaniem autorów taka interpretacja nie tylko ma uzasadnienie w cechach kształtujących samą instytucję urlopu, ale również uwzględnia funkcjonalnie rolę urlopu, jaką ten pełni w procesie organizacji procesu pracy. Nadto należy wskazać na wcześniej przytoczoną okoliczność, tj. odpowiedzialność pracodawcy za wykroczenie przeciwko prawom pracownika. Takie stanowisko wydaje się znajdować potwierdzenie w doktrynie. Jak wskazuje Zbigniew Góral, realizacja obowiązku wynikającego z art. 168 k.p. uprawnia pracodawcę do skierowania pracownika na urlop np. poprzez niedopuszczenie go do pracy ${ }^{22}$.

\section{Modyfikacja konstrukcji zaległego urlopu wypoczynkowego}

Zasadnym więc wydają się wątpliwości powstałe na tle normy wynikającej z art. $15 \mathrm{gc}$ ustawy z dnia 2 marca 2020 r. o szczególnych rozwiązaniach związanych z zapobieganiem, przeciwdziałaniem i zwalczaniem COVID-19, innych chorób zakaźnych oraz wywołanych nimi sytuacji kryzysowych (dalej: ustawa „o szczególnych rozwiązaniach...”) wprowadzonej na podstawie ustawy o dopłatach do oprocentowania kredytów bankowych udzielanych na zapewnienie płynności finansowej przedsiębiorcom dotkniętym skutkami COVID-19 oraz o zmianie niektórych ustaw ${ }^{23}$. Na podstawie wskazanej normy $\mathrm{w}$ okresie stanu epidemii lub okresie obowiązywania stanu zagrożenia

\footnotetext{
${ }^{18}$ Wyrok SN z dnia 2 września 2003 r., I PK 403/02, OSNP z 2004, Nr 18, poz. 310.

${ }^{19}$ Tamże.

${ }^{20}$ Wyrok SN z dnia 7 maja 2008 r., II PK 313/07, OSNP 2009, Nr 17-18, poz. 229.

${ }^{21}$ Postanowienie SN z dnia 25 sierpnia 2004 r., I PZP 4/04, LEX nr 1615717.

${ }^{22}$ E. Staszewska, M. Nowak Podstawowe zasady realizacji prawa do urlopu wypoczynkowego w: Urlopy pracownicze, red. Z. Góral, Warszawa 2016, s. 89.

${ }^{23}$ Ustawa z dnia 19 czerwca 2020 r. o dopłatach do oprocentowania kredytów bankowych udzielanych przedsiębiorcom dotkniętym skutkami COVID-19 oraz o uproszczonym postępowaniu o zatwierdzenie układu w związku z wystąpieniem COVID-19 (tekst jedn.: Dz.U. 2020 poz. 1086).
} 
epidemiologicznego ogłoszonego z powodu COVID-19, pracodawca może skierować pracownika na zaległy urlop wypoczynkowy. Skierowanie takie odbywa się bez uzyskania zgody pracownika oraz w terminie wskazanym przez pracodawcę. Nadto pracodawca w zakresie wskazania terminu wyznaczonego urlopu nie jest ograniczany planem urlopowym. Omawiana norma obliguje pracownika do skorzystania z wyznaczonego urlopu. Pracodawca jest jedynie ograniczony ilością dni urlopowych, na które kieruje pracownika. Uzasadnioną na gruncie obowiązującego stanu prawnego oraz części judykatury wydaje się być teza o multiplikacji możności zachowania się pracodawcy, która to zachodzi w związku z wprowadzeniem normy art. $15 \mathrm{gc}$. Wydawać by się mogło, iż przytoczona wyżej norma w żaden sposób nie wprowadza novum legislacyjnego, przeciwnie z punktu widzenia pracodawcy ogranicza szereg jego kompetencji, gdyż reżim ustawy specjalnej wprowadza ilościowe ograniczenie zaległych dni urlopowych, na które pracodawca może skierować pracownika. Jak więc należy interpretować powyższą normę? Wydaje się, iż kreacja takiego mechanizmu prawnego wynika $\mathrm{z}$ braku jednoznacznej linii orzeczniczej w zakresie kompetencji pracodawcy do udzielania oraz wysyłania pracownika na zaległy urlop. Autorzy jednak przyjmują stanowisko, zgodnie z którym w sferze możności pracodawcy dostępne jest takie działanie. Można jednak uznać, iż prawodawca dąży do likwidacji luzów interpretacyjnych pojawiających się w związku ze stosowaniem przywołanych norm. Kompetencja ta w założeniu ma redukować społeczne skutki pandemii w sferze gospodarczej przejawiającej się potencjalnym brakiem chęci wykorzystywania urlopu w związku z licznymi ograniczeniami $^{24}$. Taka diagnoza wydaje się być uprawniona. Nie sposób jednak nie dostrzec w omawianej normie funkcji dyscyplinującej, żeby uniknąć słowa - represyjnej. Pracownik bowiem ma świadomość, iż niewykorzystanie pełnej puli dostępnego w danym roku kalendarzowym urlopu będzie mogło skutkować arbitralnym wyznaczeniem dni urlopowych już u progu roku 2021. W ocenie autorów działania prawodawcy nakierowane są na likwidację problemu, jakim są niewykorzystane przez pracowników urlopy, poprzez zastosowanie mechanizmów szczególnych wprowadzonych na okres trwania pandemii COVID-19. Oczywistym jest, że ewentualne kumulowanie dni urlopowych za rok 2020 może przyczynić się do destabilizacji porządku i organizacji pracy w roku 2021, co będzie skutkować spowolnioną reakcją na pewny gospodarczy kryzys. Jednakże skutki wprowadzenia omawianej normy swoją doniosłość prawną wywrą również na gruncie stosowania norm prawa pracy w typowym stanie faktycznym. Wyposażenie pracodawcy w powyższą kompetencję może stanowić argument, iż w typowym stanie faktycznym oraz prawnym pracodawca takiej możliwości nie posiada. Rozumowanie takie swoje podstawy posiadałoby w quasi wykładni autentycznej, która w polskim systemie prawnym nie znajduje pełnego zastosowania ${ }^{25}$. Tak ukształtowana interpretacja $\mathrm{z}$ pewnością

${ }^{24}$ Uzasadnienie projektu ustawy o dopłatach do oprocentowania kredytów bankowych udzielanych na zapewnienie płynności finansowej przedsiębiorcom dotkniętym skutkami COVID-19 oraz o zmianie niektórych ustaw, s. 36.

${ }^{25}$ J. Chmielewski, Wykładnia autentyczna w praktyce orzeczniczej sądów administracyjnych, „Studia i artykuły” 2015, Nr 3, s. 47. 
może powstać na gruncie krzyżowania się dyspozycji norm wynikających z kodeksu pracy oraz art. $15 \mathrm{gc}$ ustawy „o szczególnych rozwiązaniach...”. Przyjmując za podstawę prawną normy kodeksu pracy, wskazać należy, iż pracodawca, udzielając zaległego urlopu, nie jest związany liczbą dni urlopowych, na które może skierować pracownika, ale jest ograniczony konkretnym terminem, w którym to zobowiązany jest najpóźniej do dnia 30 września udzielić pracownikowi zaległego urlopu. W omawianej normie dochodzi do swoistej zamiany ograniczeń pracodawcy. Bowiem uprawnienie do skierowania pracownika na zaległy urlop nie jest już obwarowane żadnym ograniczeniem czasowym. Wyznaczenie odbycia zaległego urlopu może więc zostać przeprowadzone także po dniu 30 września roku następnego po roku, w którym nastąpiło nabycie urlopu. W tym kontekście zasadne jest pytanie dotyczące stosowania konkretnego reżimu prawnego w stosunku do zaległego urlopu pracownika.

\section{Sfera walidacyjna}

Właściwa interpretacja omawianego zagadnienia prawnego uzależniona jest od rozstrzygnięcia, który reżim znajdzie zastosowanie w obecnym stanie faktycznym. Możliwe są dwa sposoby stosowania takich reżimów. Pierwszym z nich jest kumulatywne stosowanie norm kodeksu pracy oraz norm ustawy „o szczególnych rozwiązaniach...”. Drugim jest model rozłączny.

Chcąc zachować konsekwencję wywodu, należy wyjaśnić kwestie terminologiczne. Pod pojęciem kumulatywnego stosowania dwóch reżimów prawnych autorzy rozumieją zastosowanie powyższego modelu, w którym to pracodawca dokonuje wyboru pomiędzy podstawą prawną skierowania pracownika na zaległy urlop. Irrelewantne jest, czy zostaną zachowane reżimy wyznaczane przez normy - termin na gruncie kodeksu pracy oraz liczba dni urlopowych na podstawie ustawy „o szczególnych rozwiązaniach...”. Użycie modelu kumulatywnego oznaczać będzie zanegowanie dorobku orzeczniczego w zakresie braku konieczności uzyskania zgody pracownika na skierowanie go na urlop zaległy. Reżim ustawy specjalnej explicite zwalnia z wymogu uzyskania zgody. Rozumienie z przeciwieństwa może argumentować twierdzenie o konieczności uzyskania takiej zgody w reżimie kodeksowym.

Model rozłączny polega na czasowym wyłączeniu normy art. 168 k.p. Za takim modelem interpretacyjnym przemawiać może zawarte w normie sformułowanie „,W okresie obowiązywania stanu zagrożenia epidemicznego lub stanu epidemii”, które implikuje status omawianej normy jako normy specjalnej. Niewątpliwą zaletą takiego modelu jest jego klarowność oraz łatwość stosowania. Pracodawca w okresie stanu epidemiologicznego oraz stanu zagrożenia epidemiologicznego skorzystać może z jednej podstawy prawnej, w postaci artykułu ustawy specjalnej. Wady takiego modelu uwidaczniają się dopiero $\mathrm{w}$ sferze temporalnej. Wydaje się również, iż oddzielenie normy specjalnej od całego systemu prawa pracy i zamknięciu normy w stanie prawnym wykreowanym na potrzeby pandemii likwiduje nieścisłości interpretacyjne w postaci wątpliwości, czy pracodawca ma 
prawo arbitralnego skierowania pracownika na zaległy urlop. Wszelkie argumenty „z przeciwieństwa” będą wówczas niesłuszne, gdyż norma ta zamknie się w systemie specjalnym, nie będzie mogła rzutować na zwyczajny stan prawny jako wskazówka interpretacyjna.

\section{Sfera temporalna}

Kreując praktyczny model kumulatywnego stosowania takich norm należy wskazać, iż granicą temporalną aktualizacji właściwej normy staje się dzień 30 września. Do tego bowiem dnia pracodawca podlegałby reżimowi wynikającemu z kodeksu pracy. Natomiast po dniu 30 września podstawą skierowania pracownika na urlop zaległy stałaby się norma wynikająca z art. 15 gc ustawy „o szczególnych rozwiązaniach...”.

W ocenie autorów taki model tworzy znaczne komplikacje oraz stoi w sprzeczności z założeniami ustawy „o szczególnych rozwiązaniach...”. Właściwym przykładem unaoczniającym skalę problemu jest sytuacja, w której to liczba dni urlopowych przekracza 30 dni. W kumulatywnym modelu dopuszczamy do sytuacji, w której do 30 września udzielanie urlopu zaległego nie jest obwarowane kryterium 30 dni, natomiast po dniu 30 września aktualizacji ulegają kryteria ustawy specjalnej tj. górna granica 30 dni przeznaczonych do swobodnej dyspozycji przez pracodawcę. Dopuszczenie kumulatywnego stosowania kodeksu pracy oraz ustawy „o szczególnych rozwiązaniach" może okazać się nie tylko w sprzeczności z normami walidacyjnymi oraz literalnym brzmieniem normy prawnej, ale także z istotą wprowadzenia tejże regulacji.

W modelu rozłącznym wprowadzenie ograniczenia liczby dni urlopowych sprawia, iż omawianą normę należy określić mianem kompromisu o błędnej konstrukcji legislacyjnej. Zakładając bowiem chęć właściwego uregulowania organizacji i porządku pracy, w rzeczywistości nakładamy na pracodawcę ograniczenie ilości dni urlopowych, które to władny jest uzyskać. W zamian pracodawca dostaje bezterminowość udzielenia takiego urlopu oraz przywilej braku konieczności wyrażenia zgody pracownika, który w opinii autorów posiadał już wcześniej, w związku z dyspozycją art. 168 k.p. Prima facie takie ograniczenie powinno zostać interpretowane jako mechanizm gwarancyjny pracownika. Nie rozwiązuje jednak problemu nadmiernej liczby zaległych dni urlopowych. Jedyną zaletą wprowadzanej normy specjalnej, interpretowanej przez pryzmat modelu rozłącznego, jest rozszerzenie okresu, w którym to możliwym staje się skierowanie pracownika na zaległy urlop.

\section{Przymiot subsydiarności nowej konstrukcji urlopu wypoczynkowego}

Czy wobec powyższej analizy należy odrzucić model kumulatywny i zgodzić się na negatywne konsekwencje wynikające z błędnej konstrukcji legislacyjnej normy specjalnej? W ocenie autorów 
zastosowanie modelu rozłącznego nie realizuje podstawowego celu normy specjalnej. Jest nim przecież wsparcie pracodawcy w regulacji organizacji procesu pracy. Jedyną możliwością na nadanie normie specjalnej istotnego znaczenia w okresie pandemicznym jest wyposażenie modelu kumulatywnego w przymiot subsydiarności. Zwrot „pracodawca może udzielić pracownikowi...” powoduje, iż norma ta ma charakter zarówno specjalny, ale też subsydiarny. Przymiot specjalności kreuje przymiot subsydiarności. Subsydiarne stosowanie normy artykułu $15 \mathrm{gc}$ jest związane z funkcją zarówno normy, jak i całego aktu prawnego. Wydaje się więc, iż skorzystanie z normy $15 \mathrm{gc}$ ustawy „o szczególnych rozwiązaniach" powinno mieć miejsce w sytuacji koniecznej, kiedy plan urlopów nie pozwala w pełni realizować zasady coroczności urlopu oraz gdy pracodawca zostanie zmuszony przez okoliczności niemożliwe do przewidzenia do skorzystania z normy specjalnej. Dlatego też swoje zastosowanie znajduje w sytuacji, gdy podstawowa norma kodeksu pracy nie może zagwarantować skutecznego i efektywnego procesu i organizacji pracy. Egzemplifikując teoretyczne rozważania, słusznym wydaje się, że stosowne użycie normy art. 15gc ustawy „o szczególnych rozwiązaniach...”, będzie miało zastosowanie w sytuacji, gdy pracownicy w związku ze stanem pandemii gremialnie zaczną korzystać z mechanizmów, które w niniejszej pracy zostały określone jako te, które służą kumulacji dni urlopowych. Takimi sytuacjami może być odwołany wyjazd, który został zaplanowany z konkretnym, rozsądnym wyprzedzeniem, choroba członka rodziny. Dotyczyć to więc będzie sytuacji, w których to pracownik utracił główną bądź znaczącą część istoty urlopu. Mogą to być również sytuacje, gdy pracownik świadomie pozostawił sobie część dni urlopowych do późniejszego rozdysponowania, a które to sytuacje będą wymagały natychmiastowej reakcji pracodawcy, która na gruncie norm kodeksu pracy byłaby niemożliwa. Pracodawca więc od momentu wejścia w życie normy specjalnej z wszystkich zaległych dni urlopowych danego pracownika posiada pulę 30 dni wykorzystywanych w zmaterializowaniu się powyżej opisanych przesłanek. Liczba 30 dni nie ulega odnowieniu, bowiem norma specjalna nadaje to uprawnienie do momentu trwania stanu epidemii albo stanu zagrożenia epidemii.

Takie stanowisko nie niweluje jednak konsekwencji interpretacyjnych stosowania norm reżimu kodeksu pracy oraz reżimu na podstawie ustawy „o szczególnych rozwiązaniach...”. Wartym jednak rozważenia jest mechanizm polegający na wykorzystaniu normy specjalnej poprzez polecenie pracodawcy $\mathrm{w}$ formie pisemnego oświadczenia woli. Propozycja wprowadzenia tego formalizmu wspiera tezę o subsydiarności reguły specjalnej w sferze ewidencyjnej i dowodowej.

Dokonując powyższej analizy uwzględnić należy również stosunek omawianej normy art. $15 \mathrm{gc}$ do zasady coroczności urlopów. O ile bowiem wyjątek z kodeksu pracy w postaci art. 168 pozostaje w zgodności z tą zasadą, będąc niejako jej uzupełnieniem, to w omawianej normie owa niezgodność jest niezmiernie uwypuklona. Omawiana norma jest aktualna w stosunku do dwóch stanów: stanu zagrożenia epidemii lub stanu epidemii. Te dwa temporalne elementy wyznaczają nam okres, w którym to norma może stać się podstawą działania pracodawcy. Jednocześnie kryteria te są 
temporalną wskazówką ostatecznego terminu udzielenia zaległego urlopu. Powyższe swoje znaczenie wywiera w ramach sfery katalogu wykroczeń pracodawcy przeciwko prawom pracownika.

W doktrynie uznaje się, iż odpowiedzialność pracodawcy istnieje również w sytuacji, gdy nie udzielił pracownikowi zaległego urlopu w terminie wskazanym w art. 168 k.p. ${ }^{26}$ Wydaje się więc, iż w rzeczywistości prawnej obowiązywania normy art. 15gc ustawy „o szczególnych rozwiązaniach” nie będzie można pociągnąć pracodawcy do odpowiedzialności z tytułu wykroczenia przeciwko prawom pracownika. Nie istnieje bowiem żaden termin, który stanowi graniczny punkt w możności wyznaczania takiego urlopu, ze względu na brak możliwości wskazania, do kiedy będzie trwał stan epidemii. Ponownie jednak powraca zagadnienie „nadwyżki” dni urlopowych, tj. tych dni, które wykraczają poza ustawowo przyznane pracodawcy do arbitralnego wyznaczenia. Ujmując holistycznie cały system wsparcia pracodawców, słusznym wydaje się przyjęcie, iż pracodawca może odpowiadać jedynie za liczbę dni urlopowych stanowiących ową „nadwyżkę” w stosunku do dni przyznanych do skierowania na zaległy urlop wypoczynkowy na mocy reżimu ustawy specjalnej. W tym zakresie stanowisko autorów motywowane jest próbą utrzymania kompromisu pomiędzy gwarancyjnym charakterem całego systemu prawa pracy a newralgiczną sytuacją $\mathrm{w}$ szeroko pojętym obrocie gospodarczym, co musi stanowić podstawy do kreacji zarówno norm prawnych, jak i interpretacji pozwalających na podjęcie działań zmierzających do minimalizowania skutków pandemii.

W piśmiennictwie wskazuje się na fakt, iż wprowadzona regulacja nie posiada przymiotu „rewolucyjności”, gdyż w praktyce działanie przewidziane opisywaną normą jest już dopuszczalne ${ }^{27}$. Podzielając przytoczoną tezę, autorzy pragną zwrócić uwagę na okoliczność, która implikować może znaczne trudności $\mathrm{w}$ stosowaniu norm $\mathrm{w}$ zakresie zaległego urlopu już poza okresem pandemii COVID-19. W ocenie autorów wprowadzenie normy art. $15 \mathrm{gc}$ nie może stanowić argumentu przemawiającego za obligatoryjnością uzyskania zgody na wyznaczenie urlopu zaległego.

\section{Podsumowanie}

Podsumowując powyższe rozważania, należy stwierdzić, iż wprowadzenie normy art. $15 \mathrm{gc}$ ustawy „o szczególnych rozwiazaniach..." kreuje szansę odpowiednich regulacji procesu i organizacji pracy. Powyższe jednak uzależnione jest od właściwego stosowania omawianej normy. W opinii autorów model kumulatywny wyposażony w przymiot subsydiarności pozwala na właściwe wkomponowanie

\footnotetext{
${ }^{26}$ S. Kowalski, Wykroczenia przeciwko prawom pracownika. Postepowanie mandatowe. Komentarz do art. 281283 k.p. $i$ art. 17, 95-102a k.p.w. Komentarz. w: Kodeks pracy. Komentarz do art. 281-283, 2018, LEGALIS art. $282 \S 1$ pkt. $2 \mathrm{nb} 15$.

${ }^{27}$ M. Rotkiewicz Narzucenie pracownikowi terminu wykorzystania zalegtego urlopu w: Prawa i obowiazki pracodawcy a koronawirus, $2020 \mathrm{r}$.
} 
normy w cały system prawa pracy. Wydaje się jednak, iż konstrukcja normy może powodować później problemy z relacją pracodawca-pracownik w zakresie konieczności lub braku udzielenia zgody na urlop zaległy. Przymiot subsydiarności nadany powyższej normie powinien zapewnić holistyczną spójność systemu oraz niwelować wszelkie luzy interpretacyjne, które mogą powstać już po stanie epidemii.

\section{Bibliografia:}

\section{Akty prawne}

Ustawa z dnia 26 czerwca 1974 r. Kodeks pracy (tekst jedn.: Dz.U.1974 r. Nr 24, poz. 141 ze zm.)

Ustawa z dnia 2 marca 2020 r. o szczególnych rozwiązaniach związanych z zapobieganiem, przeciwdziałaniem i zwalczaniem COVID-19, innych chorób zakaźnych oraz wywołanych nimi sytuacji kryzysowych (tekst jedn.: Dz.U. z 2020 r. poz. 374)

Ustawa z dnia 19 czerwca 2020 r. o dopłatach do oprocentowania kredytów bankowych udzielanych przedsiębiorcom dotkniętym skutkami COVID-19 oraz o uproszczonym postępowaniu o zatwierdzenie układu w związku z wystąpieniem COVID-19 (tekst jedn.: Dz.U. 2020 poz. 1086)

\section{Orzecznictwo}

Wyrok SN z dnia 7 lutego 1967 r., I PR 53/67, OSPiKA 1967 r. z. 12, poz. 287

Wyrok SN z dnia 2 września 2003 r., I PK 403/02, OSNP z 2004 r. Nr 18, poz. 310

Postanowienie SN z dnia 25 sierpnia 2004 r., I PZP 4/04, LEX nr 1615717

Wyrok SN z dnia 7 maja 2008 r., II PK 313/07, OSNP 2009, nr 17-18, poz. 229

\section{Literatura}

Chmielewski J., Wykładnia autentyczna w praktyce orzeczniczej sądów administracyjnych, „Studia i artykuły" 2015, Nr 3

Florek L., Prawo pracy, Warszawa 2019

Jaroszewska M., Urlopy wypoczynkowe, Warszawa 2014

Kodeks pracy. Komentarz. red. A. Sobczyk, Warszawa 2020

Kodeks pracy. Komentarz. red. W. Muszalski, Warszawa 2019

Kowalski S., Kodeks pracy. Komentarz do art. 281-283, 2018

Rotkiewicz M., Prawa i obowiazki pracodawcy a koronawirus, 2020 r.

Urlopy pracownicze, red. Z. Góral, Warszawa 2016

Walczak K., Kilka uwag na temat zatrudnienia w dobie pandemii i po jej zakończeniu, Monitor Prawa Pracy 2020, Nr 6 
Wratny J., Kodeks pracy. Komentarz., Warszawa 2016

\section{Inne}

Uzasadnienie projektu ustawy o dopłatach do oprocentowania kredytów bankowych udzielanych na zapewnienie płynności finansowej przedsiębiorcom dotkniętym skutkami COVID-19 oraz o zmianie niektórych ustaw 